\title{
Emergency treatment approach and pathophysiology of burn related lung injury
}

\author{
Ahmet Özer Şehirli ${ }^{*}$ and Semra Aslay ${ }^{2}$ \\ ${ }^{1}$ Near East University, Faculty of Dentistry, Department of Pharmacology, Turkey \\ ${ }^{2}$ Near East University, Faculty of Medicine, Department of Emergency Medicine, Turkey
}

\begin{abstract}
In this review, it has been evaluated emergency treatment approach and pathogenesis of burn-related lung injury. The release of proinflammatory cytokines and the production of oxidants involved the mechanism of burn- related lung injury. In burn-induced animal models, it has been shown that oxygen radicals can be agent for local inflammatory response as well as the development of shock which burn related. Especially, it is very important that there are many deaths due to burn in emergency and still no pharmacological agent to provide radical treatment.
\end{abstract}

\section{Introduction}

Burn, heat, electricity, radiation and chemical substances, damage to the functional integrity of the skin [1]. Burn is an inflammation, sepsis, systemic inflammatory response syndrome due to the production of reactive oxygen species. Neutrophil infiltration is known to be a potential source of free oxygen radicals contributing to burn injury, and it is thought that neutrophils are responsible for the damage that occurs in local and remote areas after burns [2]. It is thought that neutrophil accumulation is significant in different tissues such as gastric mucosa, liver and lung, especially in the first phase of the burn, and neutrophils may be a source of reactive oxygen derivatives [2]. Free oxygen radicals both damage the tissue directly and allow the accumulation of polymorphonuclear leukocytes (PMNL) in that tissue. Active PMNLs from tissues reveal enzyme such as myeloperoxidase, elastase, protease, collagenase, lactoferrin, and cationic proteins. These enzymes increase both the damage on the tissue and cause the formation of more radicals. Several mediators and cytokines play an important role in the development of major complications [3-5]. In the development of these complications, the cause of the illness, duration, the layer which the illness progresses, and the immunity play an important role [6]. Especially in thermal injuries, vascular insufficiency can lead to thrombosis, increased inflammatory mediators, histamine release and edema related to increased vascular permeability, multiple organ failure and sepsis $[7,8]$. Both are the deadliest complications. That is why the most urgent step in the first 24 to 72 hours keeping the burn patient alive is the most important stage. In addition to fluid replacement in emergency resuscitation, the second important step is to reverse the destructive effect aimed at other organs. Especially in thermal burns; pulmonary damage and shock related inhalation may develop during the first week [9].

Respiratory disturbance is one of the most important causes of death after burns [10]. Local inflammation and lipid peroxidation increase in the first few hours after burn injury, which is initiated by oxidants, primarily hydroxyl radicals, leading to a significant increase in the amount of products resulting from lipid peroxidation in lung tissues within 24 hours after burn, and pulmonary it is thought that the damage is caused by oxygen radicals (Figure 1) [11,12].

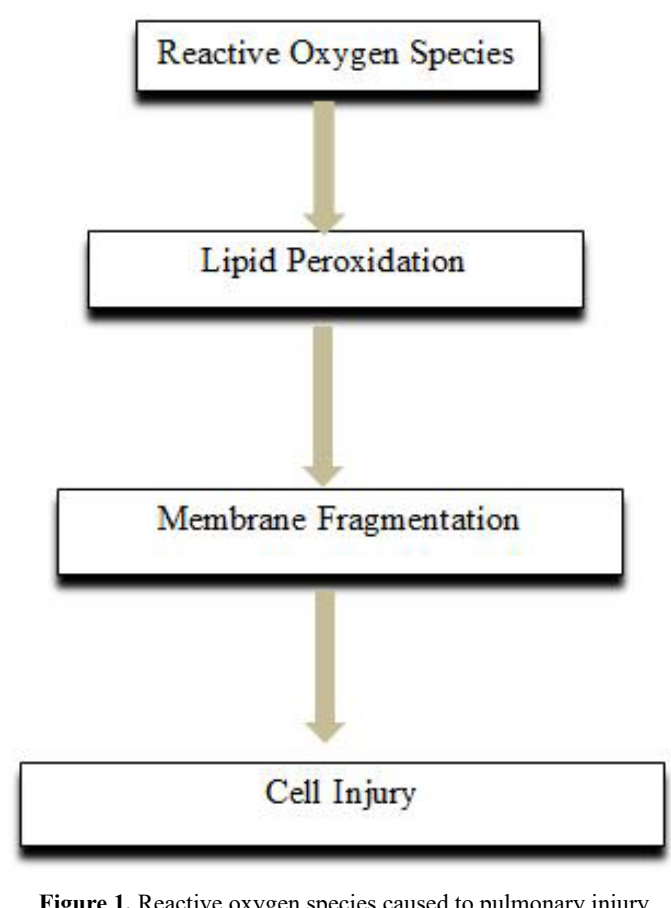

Pulmonary inflammation and lipid peroxidation are not a simple, transient initial response, on the other hand, last for at least 5 days after burn injury, and there may also be a decline in lung antioxidant defense after burn injury [13].

${ }^{*}$ Correspondence to: Ahmet Özer Şehirli, Near East University, Faculty of Medicine, Department of Emergency Medicine, Turkey, Tel: +905338215702; E-mail: ahmetozer.sehirli@neu.edu.tr

Key words: burn, oxidative damage, lung, resuscitation, emergency

Received: May 17, 2018; Accepted: May 28, 2018; Published: May 31, 2018 
Increased microvascular permeability also plays an important role in the pathogenesis of burn-related lung injury. After 24 hours after burn, widespread edema is seen in almost all patients due to burning area, formation and amount of fluid. In a study conducted to investigate the pathogenesis of lung injury, it was found that over the first 24 hours of injury, excessive fluid passage from pulmonary microvascular to interstitium [14]. In this case, the oxygen balance is disturbed due to the damage in the upper airways. Carbon monoxide level increases continuously. After diffuse bronchospasm develops, secretions increase, and oxygenation deteriorates, infection and severe respiratory failure arise [15].

\section{Hypoproteinemia related to burn and low plasma oncotic pressure}

It is thought that both physiological and immunological factors play a role in the pathophysiology of burn-related lung injury. The most important physiological factors are the effects of lower respiratory pathways due to the duration of exposure to burn, deterioration of oxygenation after epithelial damage, pneumonia due to accumulation of secretions, and death due to increased hypoxia. Inflammatory mediators such as IL-1 $\alpha$, IL-6, IL- 8 and TNF- $\alpha$ with oxygen radicals play an important role in the damage which lower respiratory tract in thermal injuries (Figure 2) [16,17]. Yet, when there is more damage, bacterial colonization in the lower respiratory tract is unavoidable and acute respiratory distress syndrome (ARDS) may develop [18].

Hypoproteinemia occurring after burn and its effect on plasma oncotic pressure are believed to be the greatest factor in fluid extravasation to the tissues $[14,19]$. This is thought to be originated from the loss of plasma proteins from the intravenous infusion of largevolume crystalloid fluids during the period of early resuscitation and

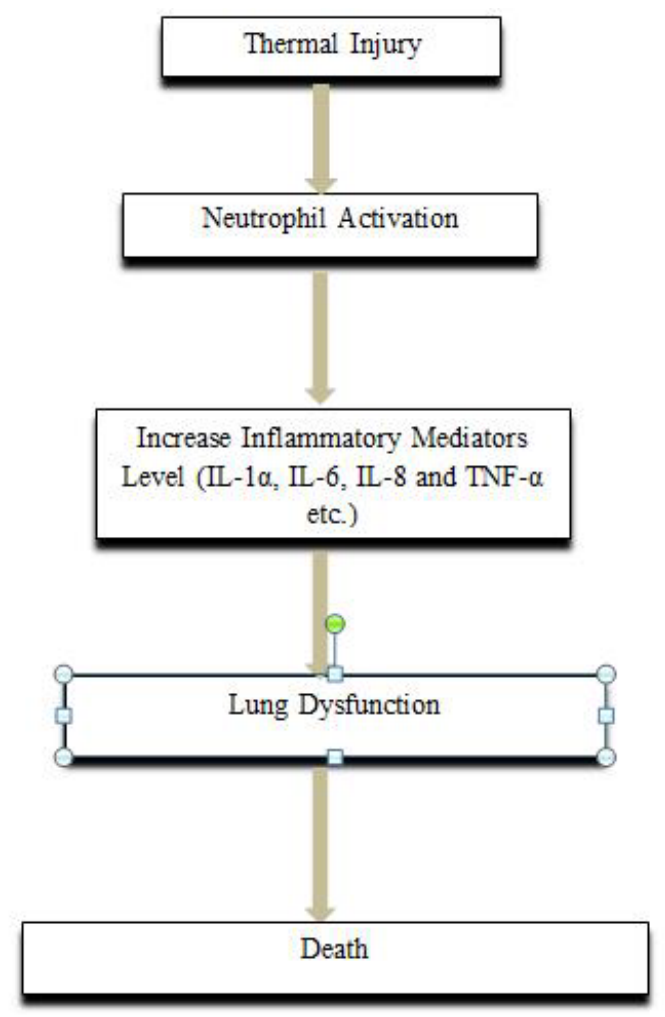

Figure 2. Inflammatory mediators such as IL-1 $\alpha$, IL-6, IL-8 and TNF- $\alpha$ with oxygen radicals play an important role in the lung damage from the burn site. Pulmonary interstitial fluid and protein movement can make the rise of hydrostatic pressure worse in pulmonary capillaries [20].

\section{Neutrophil activation based on burn injury}

In the pathogenesis of acute lung injury due to burn; complements, neutrophils and oxygen free radicals play an important role [21].

The potent initiator of vascular endothelial cell damage is neutrophils. It is thought that neutrophils have contribution on the local which comprise of the thermal injury and systemic microvascular obstruction [20]. In addition, studies have shown that decrease of neutrophil circulation or inhibition of oxidants by neutrophils in burns, which account for $40 \%$ of the total body surface area, prevents protein and fluid extravasation in the rat lung [22,23].

\section{Burn-dependent tnf-alpha release}

TNF- $\alpha$ proinflammatories are actualized their effects by directly modifying endothelial cell morphology and intercellular connectivity or by increasing neutrophil-derived cytotoxicity, which is an indirect effect [20].

It has been observed that there was an increase in TNF- $\alpha$ and other proinflammatory cytokine levels early in acute burn injury. In one study, serum concentrations of TNF- $\alpha$ in 31 patients between 1 and 6 days post-burn (mean 2 days) were reported to be 3 times higher than healthy controls. Other clinical and laboratory studies have shown that lungs are an important source for TNF- $\alpha$ release after severe burns. After 48 hours of burning in, it has been observed that TNF- $\alpha$, IL- 6 and IL-8 was in the bronchoalveolar lavage fluid of patients [24-27].

\section{Clinical findings and emergency pharmacological approach to the lung injury due to burn}

As a result of burn, hypoxemia is the most common findings. Hyperbaric oxygen treatment may be required if edema in the upper respiratory tract, accumulation of secretions in the lower airways, and persistent epithelial damage are accompanied by high carbon monoxide levels. In the treatment of fluid replacement, the Parkland formula is still accepted the "gold standard" in burn resuscitation [28,29]. Pulmonary damage may require bronchoscopy depending on the duration of exposure and the cause of the burn. A consensus decision should be applied that suggests to the tracheal aspirate $>10^{5}$, bronchoalveolar lavage in the presence of $\geq 10^{4}$ organisms should be assessed as positive for infection [30]. Ventilator support may be required when respiratory failure is severe. But, there is no specific pharmacological agent for the treatment of infection induced by damage. Treatment is dependent on microorganism types.

As a result; several clinical and laboratory studies have shown that a large number of bacteria, free oxygen radicals, and proinflammatory mediators have been involved in the pathogenesis of burn-induced lung injury. The common point in these studies is; the damage is usually caused by increased fluid movement from the vascular area to the pulmonary interstitium [20]. There have not been found any pharmalogical approaches in the approaches that have done until now. Therefore, every study of burn-related lung injury is valuable and may have the ability to create a new treatment.

\section{References}

1. Güler Ç, Bilir N (1994) Herkes için ilkyardim. Çevre Sagligi Temel Kaynak Dizisi No: 18 .

2. Parihar A, Parihar MS, Milner S, Bhat S (2008) Oxidative stress and anti-oxidative mobilization in burn injury. Burns 34: 6-17. [Crossref] 
3. Musemeche CA, Henning SJ, Baker JL, Pizzini RP (1993) Inflammatory enzyme composition of the neonatal rat intestine: implications for susceptibility to ischemia. $J$ Pediatr Surg 28: 788-791. [Crossref]

4. Otamiri T (1989) Oxygen radicals, lipid peroxidasyon, and neutrophil infiltration after small intestinal ischemia and reperfusion. Surgery 105: 593-597.

5. Schoenberg MH, Muhl E, Sellin D, Younes M, Schildberg FW, et al. (1984) Posthypotensive generation of superoxide free radicals--possible role in the pathogenesis of the intestinal mucosal damage. Acta Chir Scand 150: 301-309. [Crossref]

6. Zor F, Ersöz N, Külahçi Y, Kapi E, Bozkurt M (2009) Birinci Basamak Yanik Tedavisinde Altin Standartlar. Dicle Tip Dergisi 36: 219-225.

7. Bohr S, Patel SJ, Shen K (2013) Alternative erythropoietinmediated signaling prevents secondary microvascular thrombosis and inflammation within cutaneous burns. Proc Natl Acad Sci USA 110: 3513-8.

8. Hussain A, Dunn KW (2013) Predicting length of stay in thermal burns: a systematic review of prognostic factors. Burns39: 1331-40.

9. Swanson JW, Otto AM, Gibran NS, Klein MB, Kramer CB, et al. (2013) Trajectories to death in patients with burn injury. J Trauma Acute Care Surg 74: 282-288. [Crossref]

10. Till GO, Beauchamp C, Menapace D, Tourtellotte W Jr, Kunkel R, et al. (1983) Oxygen radical dependent lung damage following thermal injury of rat skin. $J$ Trauma 23: 269277. [Crossref]

11. Sener G, Sehirli AO, SatiroÄŸlu H, Keyer-Uysal M, YeÄŸen BC (2002) Melatonin improves oxidative organ damage in a rat model of thermal injury. Burns 28: 419425. [Crossref]

12. Mercury AA, Sold B, Trigger, Green, Green B, et al. (2016) Protective effect of betaine against burn-induced pulmonary injury in rats. Ulus Travma Acil Cerrahi Derg 22: 417-422. [Crossref]

13. Demling RH, Lalonde C, Liu YP, Zhu DG (1989) The lung inflammatory response from thermal injury (relationship between physiological and histological changes). Surgery 106: 52-9.

14. Demling RH, Kramer G, Harms B (1984) Role of thermal injury-induced hypoproteinemia on fluid flux and protein permeability in burned and unburned tissue. Surgery 95: 136-44.

15. You K, Yang HT, Kym D, Yoon J, HaejunYim, et al. (2014) Inhalation injury in burn patients: establishing the link between diagnosis and prognosis. Burns 40: 1470-1475. [Crossref]

16. Vaughn L, Beckel N (2012) Severe burn injury, burn shock, and smoke inhalation injury in small animals. Part 1: burn classification and pathophysiology. $J$ Vet Emerg Crit Care (San Antonio) 22: 179-86.
17. Wu D, Yuehong S, Qiang L, Shouyin J, Huahao S (2018) Therapeutic mild hypothermia improves early outcomes in rats subjected to severe sepsis. Life Sci S0024-3205: 30100-0.

18. Asmussen S, Maybauer DM, Fraser JF, Jennings K, George S, Keiralla A, Maybauer MO. Extracorporeal membrane oxygenation in burn and smoke inhalation injury. Burns 2013;39: 429-35.

19. Lund T, Onarheim H, Reed RK (1992) Pathogenesis of edema formation in burn injuries. World J Surg 16: 2-9. [Crossref]

20. Turnage RH, Nwariaku F, Murphy J, Schulman C, Wright K, et al. (2002) Mechanisms of pulmonary microvascular dysfunction during severe burn injury. World J Surg 26: 848-853. [Crossref]

21. Ward PA, Till GO (1990) Pathophysiologic events related to thermal injury of skin. $J$ Trauma 30: S75-79. [Crossref]

22. Till GO, Hatherill JR, Tourtellotte WW, Lutz MJ, Ward PA (1985) Lipid peroxidation and acute lung injury after thermal trauma to skin. Evidence of a role for hydroxyl radical. Am J Pathol 119: 376-84.

23. Till GO, Beauchamp C, Menapace D, Tourtellotte W Jr, Kunkel R, et al. (1983) Oxygen radical dependent lung damage following thermal injury of rat skin. J Trauma 23: 269277. [Crossref]

24. Aykac A, Karanlik B, Sehirli AO (2018) Protective effect of silk fibroin in burn injury in rat model. Gene 641: 287-291. [Crossref]

25. Saglam E, Sehirli AO, Ozdamar EN, Contuk G, Cetinel S, et al. (2014) Captopril protects against burn-induced cardiopulmonary injury in rats. Ulus Travma Acil Cerrahi Derg 20: 151-160.

26. Sakarcan A, Sehirli O, Velioglu-Ovünç A, Ercan F, Erkanl G, et al. (2005) Ginkgo biloba extract improves oxidative organ damage in a rat model of thermal trauma. $J$ Burn Care Rehabil 26: 515-24.

27. Rice TC, Seitz AP, Edwards MJ, Gulbins E, Caldwell CC (2016) Frontline Science: Sphingosine rescues burn-injured mice from pulmonary Pseudomonas aeruginosa infection. J Leukoc Biol 100: 1233-1237.

28. Greenhalgh DG (2007) Burn resuscitation. J Burn Care Res 28: 555-565. [Crossref]

29. Friedrich JB, Sullivan SR, Engrav LH, Round KA, Blayney CB, et al. (2004) Is supra-Baxter resuscitation in burn patients a new phenomenon? Burns 30: 464-466. [Crossref]

30. Rello J, Paiva JA, Baraibar J, Barcenilla F, Bodi M, et al. (2002) International Conference for the Development of Consensus on the Diagnosis and Treatment of Ventilator-Associated Pneumonia. Chest 120: 955-970.

Copyright: $\odot 2018$ Şehirli AÖ. This is an open-access article distributed under the terms of the Creative Commons Attribution License, which permits unrestricted use, distribution, and reproduction in any medium, provided the original author and source are credited. 